\title{
Tutkimus taipuu teemaksi
}

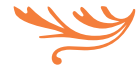

Hyvä teemanumero hengittää yli tieteenalan rajojen.

Laadukas tutkimus ja ennakkoluulottomat ratkaisut

tuottavat yllätyksellisen ja kiinnostavan paketin.
\end{abstract}

Joskus päätoimittajan unelmat toteutuvat. Sähköpostiin tipahtaa viesti, jossa tutkijaporukka ehdottaa teemanumeroa. On valmiit jutut, muutama tiedeartikkeli, puheenvuoroja ja kirja-arvioita. On lupaus toimitustyöstä ja aikataulut.

Tällaiset hetket ovat olleet maantieteilijöiden Terra-aikakauskirjaa päätoimittaneelle Hannu Linkolalle tiedelehtiuran kohokohtia.

"Olisivatpa kaikki numerot tällaisia", hän muistaa ajatelleensa.

Valmis teemapaketti keventää päätoimittajan ja toimituskunnan työtaakkaa. Vielä tärkeämpää on kuitenkin se, että toimituksen ulkopuolelta saadaan tuoreita ideoita ja näkökulmia.

Kun julkaisuprosessi etenee suunnitelmien mukaan, Linkolan kokemuksen mukaan noin yhdeksän kuukautta ensimmäisestä sähköpostista julkaistaan teemanumero, joka avaa jotakin aihepiiriä tuoreesta näkökulmasta.

Toisinkin voi tosin käydä.

Linkolalla on kokemusta esimerkiksi sellaisesta, että alkuun kiinnostavalta vaikuttava, ajankohtainen teema osoittautuu esimerkiksi poliittisesti arkaluontoiseksi. Silloin on vaarana, että teema tylsistyy

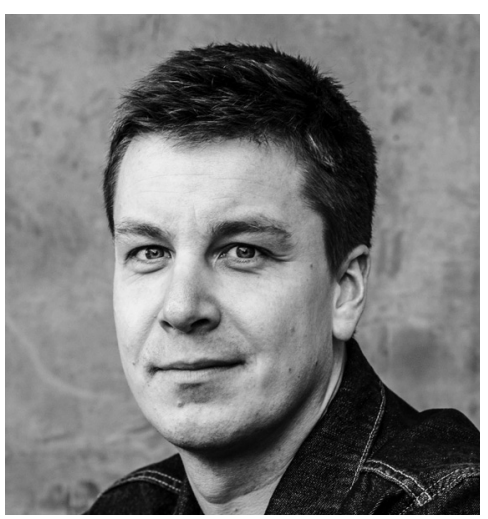

Linkola päätoimitti Suomen Maantieteellisen Seuran aikakauskirjaa Terraa vuosina 2014-2019.

kriittisyyden puutteeseen ja hampaattomaaseen tutkimukseen.

Ilman laadukasta vertaisarvioitua tutkimusta ei nimittäin synny laadukasta teemanumeroa.

Muitakin ehtoja on, mutta ennen kaikkea päätoimittajalta vaaditaan herkkiä tuntosarvia sen suhteen, mihin kannattaa tarttua. Hänen on kysyttävä itseltään, onko tässä jotain oikeasti uutta. 


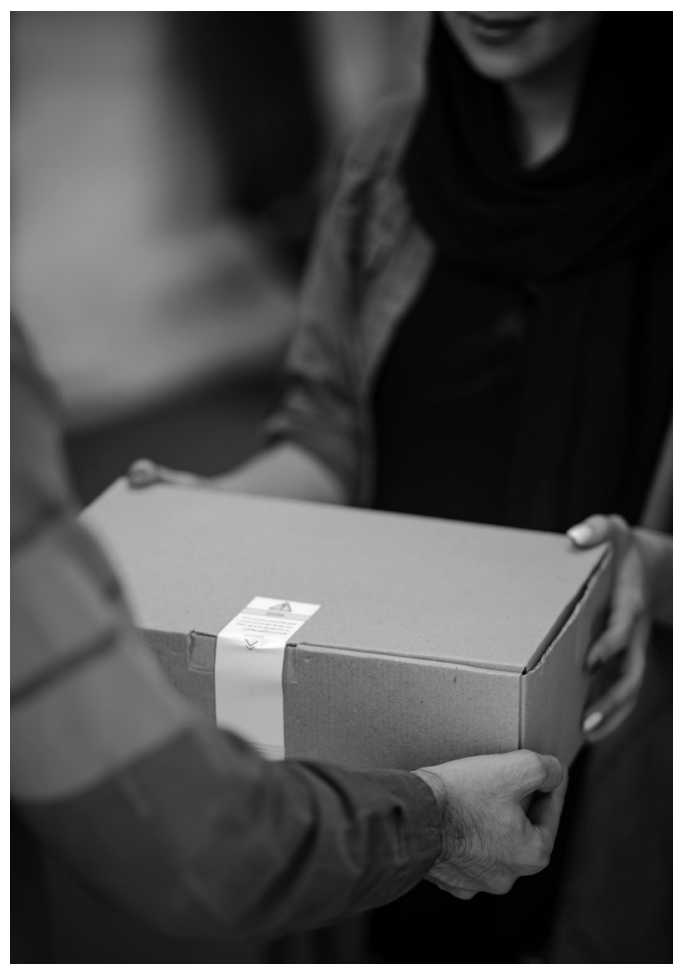

Toisinaan päätoimittajalle tarjotaan valmista teemanumeropakettia. Useimmiten sisällöt kootaan toimituskunnan voimin.

\section{Tuumasta teemaan}

Onko sinulla meneillään tutkimus, jossa on mahdollisuuksia vuoropuheluun, syventämiseen ja laventamiseen? Laadi teemaehdotus Aikuiskasvatukseen ja kerro,

- miksi teema pitää tehdä

- keitä se kiinnostaa ja missä kiinnostuneet ovat

- keitä halutaan mukaan ja miksi

- millaiset omat roolinne ovat

- millaista tutkimusta ja materiaalia aihepiiristä on olemassa

- mitä toimintaa, kuten tutkimushankkeita, teeman ympärillä on

- millaisin sisällöin teema toteutetaan

- millaisella aikataululla teema syntyy

- miten teema markkinoidaan lukijoille

- mistä teemaan voi hakea rahoitusta.
P $\ddot{A}$ TOIMITTAJALTA VAADITAAN

\section{HERKKI $\dddot{A}$ TUNTOSARVIA SEN}

SUHTEEN, MIHIN AIHEISIIN

KANNATTAA TARTTUA.

\section{AIKATAULUSTA ALKUUN}

Maantieteilijöiden Terrassa neljästä vuosittaisesta numerosta yksi on teemoitettu. Aiheiden kirjo on yhtä lavea kuin julkaisun kattama alue.

"Tyypillisesti teemanumero tulee tarjouksena tai päätoimittaja huomaa kiinnostavan aihepiirin, josta tilaa teemanumeron. Tai jotain siltä välillä”, Linkola kuvailee.

Julkaisuprosessin alkajaiseksi on laadittava aikataulu, jossa on väljyyttä kaikille vaadittaville työvaiheille mutta joka on niin tiukka, että aiheen mahdollinen ajankohtaisarvo ei vaarannu. Tavallisesti teeman suunnittelu alkaa noin vuotta ennen numeron julkaisemista.

Kun aikataulu eri vaiheineen on selvä, lähetetään kirjoittajakutsuja ympäriinsä, työstetään käsikirjoituksia, pyöritetään refereekierroksia sekä varaudutaan kesälomien ja koko yliopistomaailmaa ruuhkauttavien isojen rahoitushakujen aiheuttamiin viiveisiin. Muutama viikko on syytä varata sille, että tekstit saadaan keskustelemaan keskenään.

"Hyvä tapa on luetuttaa tekstejä ristiin kirjoittajilla, jotta saadaan aikaan hedelmällistä vuoropuhelua", Linkola vinkkaa.

Toisinaan toimituskunta joutuu haalimaan numeroon tilkepaloiksi vaikkapa puheenvuoroja tai muita tekstejä, jotta sisällön painotukset saadaan kuntoon.

\section{LEHTI PITÄÄ KIINNI LINJASTAAN}

Julkaisuprosessit vaihtelevat julkaisuittain, niin myös tavat paketoida tutkimus teemanumeroksi. Teema voi syntyä toimituskunnan voimin, tai mukaan kutsutaan vierailevat toimittajat. Vierailevan toimittajan 


\section{Tutkimuspäiviltä idea akateemisen yrittäjyyden numeroon}

\begin{abstract}
Aikuiskasvatus julkaisee vuosittain yhden toimitetun teemanumeron. Tuorein teema syntyi akateemisesta yrittäjyydestä. Idea syntyi lennossa ja kehkeytyi toimituskunnassa julkaisuksi.

"Saimme Aikuiskasvatuksen tutkimuspäivillä 2018 korkeakoulutuksen tutkimuksen teemaryhmään kiinnostavia esityksiä yrittäjyydestä. Samaan aikaan käynnissä oli Suomen Akatemian rahoittama Akateeminen yrittäjyys sosiaalisena prosessina -hanke. Kun päätoimittaja näytti vihreää valoa, kutsuin teemaryhmäläisiä kirjoittamaan Aikuiskasvatukseen", teeman vastuutoimittaja, yliopistotutkija Päivi Siivonen kertoo.

Yrittäjyysteemaa perustelivat aiheen ajankohtaisuus ja sitä koskevan tutkimuksen puute. Lisäksi aihe on sidoksissa korkeakorkeakoulupolitiikkaan ja käytäntöjen muotoutumiseen korkeakoulutuksessa.
\end{abstract}

Aikuiskasvatuksen teemoissa noudatetaan lehden normaalia julkaisuprosessia refereekierroksineen. Akateemisen yrittäjyyden numerossa

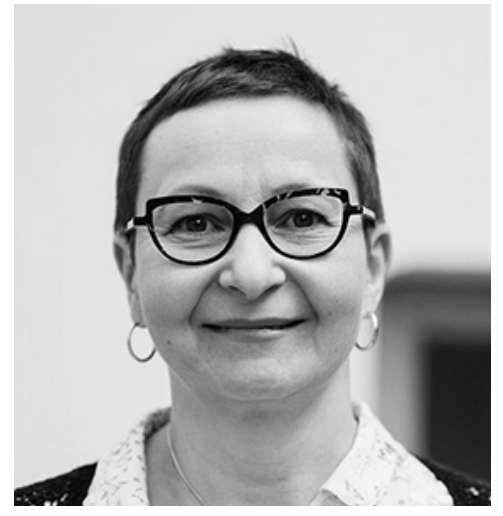

Päivi Siivonen

tiedeartikkeleita täydensivät puheenvuorot ja kirja-arviot. Pääkirjoituksessaan Siivonen punoi langat yhteen ja avasi perspektiiviä laveammalle yhteiskuntaan.

"Syntyi hieno ja kiinnostava teemanumero", vastuutoimittaja sanoo. vastuu saattaa ulottua aineiston kokoamisesta itse toimitustyöhön.

Terrassa vastuu teemanumerosta kuuluu päätoimittajalle, vaikka numeron rungon kokoaakin vieraileva toimittaja. Kannattaa kuitenkin olla avoin eri muodoille ja roolituksille, Linkola kannustaa.

Teemanumeron tärkein voimavara ovat kirjoittajat, alansa luotettavat asiantuntijat.

"Heitä on saatava mukaan eri paikoista, jotta näkökulmien monipuolisuus taataan. Uusia tekijöitä löytää tieteenalan tapahtumista, kuten konferensseista ja koulutuksista. Opiskelijoita voi kutsua tekemään kirja-arvioita”, Linkola vinkkaa.

Kun mukaan kutsutaan ulkopuolinen päätoimittaja tai toimituskunta, julkaisupolitiikkaa on syytä avata huolellisesti. Muuten vaarana on sotkuinen soppa. Päätösvaltaa ei voi eikä saa antaa toimituksen ulkopuolelle.

"Toimituskunnalla saattaa olla erilainen käsitys lehden linjasta ja tarkoituksesta. Esimerkiksi pelkkään poliittiseen argumentointiin tai tarkoitusperiin tukeutuva teksti ei kuulu tiedejulkaisuun”, Hannu Linkola antaa esimerkin.

Omat mutkansa monitieteisen teemanumeron julkaisuprosessiin tuovat toisinaan eri tieteenalojen kirjoituskulttuurit. Käsitteitä ja traditioita joudutaan sovittelemaan puolin ja toisin.

"Kun kaikki menee hyvin ja sovitusti, päätoimittaja seuraa tilannetta, tarkentaa ohjeistusta tarvittaessa ja koordinoi. Ja lopulta eri traditiot ja näkökulmat saadaan rikastamaan toinen toisiaan riitelyn sijasta”, Linkola sanoo. 


\section{SIJAA SATTUMILLE}

Teemanumero yllättää aina. Vaikka julkaisuprosessi olisi kuinka hallittu, lopputulos harvoin vastaa tismalleen sitä, mistä lähdettiin liikkeelle. Yleensä se on hyvä asia, joskus se voi olla paha asia. Teemaan jää, ja on syytäkin jättää, sijaa sattumille.

Onnistunut teema lunastaa lupauksensa aihepiirin syventämisestä ja näkökulmien avaamisesta. Se vahvistaa monitieteistä vuoropuhelua aihepiiristä. Teemanumero on sisällöiltään monipuolinen mutta silti yhtenäinen. Vahva punainen lanka ulottuu juttutyypistä toiseen, kannesta kanteen.
"Koko numeroa ei silti tarvitse teemoittaa, vaan sisällöissä saa olla vaihtelua. Pääkirjoitus viimeistelee numeron rakentamalla siihen temaattisen jännitteen", Hannu Linkola huomauttaa.

Kokenut päätoimittaja vinkkaa, että aina ei ole tarpeen ryhtyä mittavaan, aikaa ja voimia vaativaan teemanumerohankkeeseen, vaan julkaisulle tarjottuja käsikirjoituksia kannattaa tarkastella sillä silmällä, syntyisikö niistä miniteemoja. Tiedeartikkeleita, näkökulmia ja puheenvuoroja voi täydentää haastatteluilla ja kirja-arvioilla.

Suomen tiedekustantajien liitto järjesti koulutuksen teemanumeroista ja artikkelikokoelmista tieteellisten julkaisujen toimittajille lokakuussa 2019 Tieteiden talolla Helsingissä.

\title{
Tulevien numeroiden kirjoittajakutsut
}

\author{
Aikuiskasvatus katsoo teemanumeroissaan laajasti yhteiskuntaan. \\ Osallistu tieteenalojen rajat ylittävään keskusteluun omalla tekstillä.
}

\section{AIKUISKOULUTUSPOLITIIKKA, 4/2020}

Mitä sanottavaa kasvatustieteen ja aikuiskasvatustieteen tutkijoilla on Suomen aikuiskoulutuspolitiikasta?

Koulutuspolitiikkaan tuli 2010-luvun lopulla jatkuvan oppimisen käsite. Hallitusohjelmaan taas sisältyy jatkuvan oppimisen uudistaminen, jossa korostuvat työurien pidentäminen, työllisyyden parantaminen, julkistalouden tasapaino sekä yritysten kilpailukyvyn ja tuottavuuden parantaminen.

Aikuisten kouluttamista sanoitetaan pitkälti työelämän, elinkeinopolitiikan ja talouden käsittein, vaikka kyse on aikuisten oppimisesta, kehittymisestä ja kouluttautumisesta.

Aikuiskoulutuspolitiikan teemanumeroon haetaan kriittisiä ja monipuolisia tekstejä, jotka käsittelevät aihetta eri näkökulmasta. 'Politiikalla' tarkoitetaan laajasti politiikan tekemistä, toimintapolitiikkoja ja erilaisia kamppailuja aikuiskoulutukseen kytköksissä olevilla kentillä.

Politiikkaa tekevät monet tahot kansallisesti ja ylikansallisesti. Politiikan kohteina ovat niin ikään eri tasojen toimijat, rakenteet ja instituutiot, viime kädessä kansalaiset.
Teemanumeron tekstit voivat etsiä vastauksia esimerkiksi siihen,

- miten aikuiskoulutusta koskevia päätöksiä tehdään, miten syntyvät linjaukset aikuisten kouluttamiseksi ja mitä aikuiskoulutuspolitiikalla tuotetaan

- missä osaamisen kehittämisen politiikkaa tehdään ja kenen ehdoilla

- millaisia toimijoita tutkijat ovat suhteessa aikuiskoulutuskoulutuspolitiikkaan

- millaisilla työkaluilla ja tekniikoilla politiikkoja toteutetaan

- miten politiikat vaikuttavat instituutioihin, rakenteisiin ja käytänteisiin.

\section{Aikataulut: tiedeartikkelien käsikirjoitukset viimeistään 29 . toukokuuta; näkökulmat, pu- heenvuorot ja kirja-arviot ehti- vät viimeistään 7 . elokuuta. \\ Toimituskunnassa numerosta vastaa Nina Haltia.}


Planetaariset kriisit haastavat etsimään uusia ajattelun ja oppimisen toimintatapoja. Miten sivistystyö voisi edistää sosiaalista, taloudellista ja ekologista kestävyyttä?

Teemanumerossa keskitytään ekososiaaliseen sivistykseen, jota tarkastellaan planetaarisuuden ja kestävän kehityksen näkökulmista.

Ekososiaalinen sivistys on muutosvoima, jossa yhteisöt luovat yhdessä laajenevan, demokraattisen, kaiken elävän biologista ja kulttuurista monimuotoisuutta kunnioittavan tilan. Työ ja ammatillinen toiminta kuuluvat ekososiaalisen sivistyksen tarkasteluun, sillä ne ovat vahvasti sidoksissa suomalaisen sivistyskäsitteen määrittelyihin. Samalla ne ovat perustavia vapaan sivistystyön identiteetille.

Teemanumero juhlistaa Sivistystyön vapaus ja vastuu (SVV) -ohjelman kymmenvuotisuutta. SVV tukee vapaan sivistystyön tutkimusta ja koulutusta, alan tutkijoiden ja toimijoiden vuorovaikutusta sekä yhteiskunnallista vaikuttamista.

\section{TUTKIJA JA AKTIVISTI, 1/2022}

Tutkimusta tehdään, jotta ymmärretään paremmin todellisuutta. Joskus lisääntynyt ymmärrys saattaa johtaa siihen, että vallalla oleva kehityskulku pitää kääntää.

- Millaisen roolin tutkija ottaa yhteiskunnassa törmätessään korjaamista vaativiin epäkohtiin?

- Kuinka akateemisuus ja aktivismi sovitetaan yhteen?

- Onko olemassa tutkimusta, joka kantaaottavuudessaan lähentyy aktivismia?

Akateemisen aktivismin teemanumerossa paneudutaan tutkijan ja aktivistin roolien väliseen jännitteeseen.

Tutkimuksen poliittisuus, vahvistuva eettisyyden tarve monimutkaistuneessa maailmassa ja dystooppiset
Teemanumeroon etsitään käsikirjoituksia, jotka käsittelevät ekososiaalista sivistystä, planetaarisia kriisejä tai kestävää kehitystä aikuiskasvatuksen ja vapaan sivistystyön kontekstissa. Tekstit voivat vastata esimerkiksi

- sivistyksen ja vapaan sivistystyön rooliin planetaarisissa kriiseissä ennen, nyt ja tulevaisuudessa

- ekososiaalisen sivistyksen rooliin globaalien haasteiden aikakaudella

- vapaan sivistystyön suhteeseen työhön, talouteen ja ammatteihin.

Käsikirjoituksia pyydetään aikuiskasvatusalan toimijoiden ohella köyhyys-, yhteiskunta-, ilmasto-, ympäristö- sekä media-alan asiantuntijoilta.

Toimituskunnassa numerosta vastaa Hanna Toiviainen.

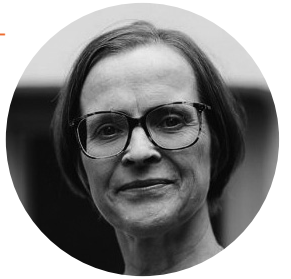

tulevaisuuskuvat vaativat tutkijaa asemoitumaan uudella tavalla yhteiskunnassa.

Näkökulmana aktivismiin voi olla esimerkiksi elämän edellytysten jatkuminen, tasa-arvon kysymykset tai aktiivinen kansalaisuus.

Käsikirjoitukset voivat olla yhtä hyvin aikuiskasvatuksen ytimessä kuin tieteiden rajat ylittäviä, teoreettisia, käsitteellisiä tai empiirisiä.

Toimituskunnassa numerosta vastaa Arto O. Salonen.

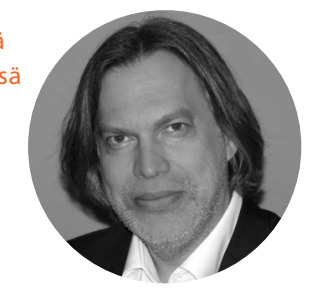

NÄIN TARJOAT KÄSIKIRJOITUSTA TEEMANUMEROON

- Tutustu Aikuiskasvatuksen kirjoittajaohjeisiin.

- Mieti erityisesti, miksi käsikirjoituksesi on ajankohtainen juuri nyt ja minkä asian haluat sillä tuoda keskusteluun.

- Lähetä artikkelin käsikirjoitus toimitukseen (terhi.kouvo@kvs.fi).

Lisätiedot:

toimituspäällikkö Terhi Kouvo, 0400396 437, terhi.kouvo@kvs.fi 